\title{
PERFORMANCE EVALUATING OF RURAL ICT CENTERS (TELECENTERS), APPLYING FUZZY AHP, SAW-G AND TOPSIS GREY, A CASE STUDY IN IRAN
}

\author{
Sarfaraz Hashemkhani Zolfani ${ }^{1}$, Maedeh Sedaghat ${ }^{2}$, Edmundas Kazimieras Zavadskas ${ }^{3}$
}

\author{
${ }^{1}$ Shomal University, Department of Industrial Engineering, P. O. Box 731, Amol, Mazandaran, Iran \\ ${ }^{2}$ Young Research Club, Sari Branch Azad University, P. O. Box 194-48164, Sari, Iran \\ ${ }^{3}$ Vilnius Gediminas Technical University, Institute of Internet and Intelligent Technologies, \\ Sauletekio al. 11, LT-10223 Vilnius, Lithuania \\ E-mails: ${ }^{1}$ sa.hashemkhani@gmail.com; ${ }^{2}$ sedaghat.maedeh@yahoo.com; \\ ${ }^{3}$ edmundas.zavadskas@vgtu.lt (correspondingauthor)
}

Received 30 December 2011; accepted 07 April 2012

\begin{abstract}
The project of developing technology in villages was an important project in Iran which was finished in 2010 but it's still being pursued to develop its related services. This project includes many major and minor objectives. After passing six years from the beginning of this project, it seems reasonable to do research about evaluating the progress of these centers. Hence, a framework of evaluation is presented studying past researches utilizing the following criteria; public training, classic training, special training, cultural services, social services, governmental services and other services. Three MCDM methods are applied for evaluating; Fuzzy AHP is used for calculating weights of each criteria and sub-criteria and SAW-G and TOPSIS Grey are applied for evaluating alternatives. Three rural ICT centers are selected as a case study which are located in Golestan Province in north of Iran. The findings show that due to new services presented in these areas, public training and cultural services are more important criteria. Results of SAW-G and TOPSIS Grey are the same which both selected Gharnabad ICT center as the best center and Livan and Bala Jadeh centers are placed as the second and third, respectively.
\end{abstract}

Keywords: performance evaluation, rural ICT center, Fuzzy AHP, SAW-G, TOPSIS Grey.

Reference to this paper should be made as follows: Hashemkhani Zolfani, S.; Sedaghat, M.; Zavadskas, E. K. 2012. Performance evaluating of rural ICT centers (telecenters), applying Fuzzy AHP, SAW-G and TOPSIS Grey, a case study in Iran, Technological and Economic Development of Economy 18(2): 364-387.

JEL Classification: C44, O18, O31, D81. 


\section{Introduction}

Telecenters (places where shared access to information and communication technology (ICT) and IT enabled services are available) are considered a potential instrument for addressing the asymmetric information problem and the digital divide, and therefore as development enablers (Fillip, Foote 2007). The World Summit on Information Society held in 2003 recognized telecenters as a cost effective way of bringing the information revolution to developing countries, and thus endowed with the potential to empower the poor. There are instances of E-Government projects of this nature in some countries that have yielded significant positive gains for the poor (Bhatnagar 2009).

The growing concern is that poor people, especially those in rural areas, have benefited very little from rapid economic growth. While the migration of the rural poor to urban areas has helped cater to urban requirements, it has accentuated urban poverty and migration related social problems. Asymmetric information coupled with poor skill sets are considered the root cause of the inability of the rural poor to take advantage of opportunities in the markets created by technology advancement and policy changes. Addressing the problem of asymmetric information is expected to empower the rural poor to take advantage of the market opportunities as well as overcome the skill set deficits in the long run and therefore enhances inclusiveness. This would also contribute to faster and more balanced growth of the economy.

Last decade has also seen a marked increase in the number of projects in developing countries that use information and communication technologies (ICTs) for social, economic, and political development (Toyama et al. 2004). A large number of these projects aim at bringing the benefits of ICTs to communities where individual ownership of computers is low and use of the Internet is infrequent (Best, Kumar 2008). This trend illustrates the high and everincreasing expectations placed on ICT in terms of bringing about improvement in quality of life, empowerment and economic development for the rural communities (Hosman, Fife 2008). The prevalent method of reaching out to rural areas in these projects has been telecenters (Heeks 2008) which provide shared public access, often intermediated by an operator, to information and communication technologies and services via computers and the Internet.

Apart from many other areas, rural communities in Iran still depend on agriculture and small-scale trading for livelihoods. Through a telecenter, the community is able to access information resources on farming practices via access business information resources to expand their businesses. They use a local center as a communication platform for products and services. Through skills training services, telecenters help to build a skill base for local business. Traders place online business orders with urban suppliers.

The idea behind these shared-access facilities is that while the goal of providing all households access to ICT, that is, universal service, is not possible for most people of the world, providing shared access is possible, particularly with the rapid evolution of technology. Through the use of Internet and mobile technology services, the communities are able to access social and economic services that could have been difficult without their presence. Telecenters have developed and offer services through social enterprising models that balance between social aspects of the communities therefore offering economic empowerment opportunities to the rural population. 
The importance of development and utilizing information and communication technology and their applications in villages will get greater importance by knowing that more than $40 \%$ of world population live in villages, rural population in the region of Asia and Oceania is $60 \%$ and in Iran they consist 30\% of total population. More than 1 billion around the world don't know much about primary tools of information and communication technology. Although, regarding the issue of rural urban migration, development of information and communication technologies in villages has found a special place. There are 68200 villages in Iran, of which nearly 50,000 are equipped with telecommunication instruments and facilities, but in our country, development of information and communication technologies has not been achieved practically and in reality (Jalali et al. 2005; Hashemkhani Zolfani et al. 2011).

20 year landscape of cultural, economic and social development of Iran has been set up based on wisdom, therefore it is prescribed that people must have the opportunity of accessing information; as a result, relatively good and considerable actions in development of rural information and communication technologies have been started in the country. Having strategic document of rural information and communication technologies helps to integrate and coordinate all actions that must be done in country by governmental and private sectors and this will help prevent additional costs (Ministry of IT and Communication 2004; Hashemkhani Zolfani et al. 2011).

Some general roles of the rural telecenter can be defined as follows: creating a knowledge center in rural community, educating people and enriching living standards, realizing grass roots access to global information through the Internet, promoting the sale of local products through the Internet and e-Commerce, providing government information such as natural disaster warning to local communities, and attracting visitors from all over the world by demonstrating local culture and beautiful scenery.

The project of equipping 10,000 villages of country with rural information and communicative technology offices (Rural Telecenters) had been started from 2005 and finally was finished in 2010. The process of developing project of rural ICT centers in Iran is shown in Table 1.

After accomplishing the wide project of equipping rural areas, it seems that this project needs evaluating the facilities and equipment of rural ICT centers (Rural Telecenters). These centers aren't the same as others. The aim of this research is performance evaluation of rural ICT centers in Iran which was established more than 3 years ago and we are going to compare the achievements (if any) with the main purposes of establishing them. In this regard, 3 rural ICT centers have been selected as case studies. In this research, after identifying important criteria from literature review, Fuzzy AHP is applied for calculating weight of each criterion and then 3 rural ICT center are evaluated by SAW-G and TOPSIS GREY. The process of evaluating rural ICT centers is shown in Figure 1. 
Table 1. Comparative comparison of Iran's telecom network performance between 2005 and 2010

\begin{tabular}{|c|c|c|c|c|c|c|c|}
\hline & Index & 2005 & 2006 & 2007 & 2008 & 2009 & 2010 \\
\hline 1 & $\begin{array}{l}\text { Fixed telephone } \\
\text { diary }\end{array}$ & 20340060 & 22626944 & 2352089 & 24709447 & 25410361 & 25466778 \\
\hline 2 & $\begin{array}{l}\text { Penetration index } \\
\text { of fixed telephone }\end{array}$ & $29 / 71$ & $32 / 57$ & $33 / 45$ & $33 / 95$ & $34 / 04$ & 34.40 \\
\hline 3 & Mobile phone diary & 8510513 & 15385289 & 24509714 & 31423104 & 35427101 & 42000000 \\
\hline 4 & $\begin{array}{l}\text { Penetration index } \\
\text { of mobile phone }\end{array}$ & $12 / 43$ & $22 / 20$ & $34 / 20$ & $43 / 20$ & $47 / 90$ & 53.10 \\
\hline 5 & $\begin{array}{l}\text { Villages that have } \\
\text { communication }\end{array}$ & 47955 & 51058 & 52784 & 53845 & 52596 & 53000 \\
\hline 6 & Rural ICT Centers & 963 & 2287 & 5590 & 8200 & 9812 & 10000 \\
\hline 7 & $\begin{array}{l}\text { Urban public } \\
\text { telephone }\end{array}$ & 141912 & 167366 & 186198 & 217819 & 228000 & 241000 \\
\hline 8 & $\begin{array}{l}\text { Remote public } \\
\text { telephones }\end{array}$ & 64774 & 89460 & 124314 & 162055 & 176600 & 186000 \\
\hline 9 & Data access ports & 14897 & 16392 & 36806 & 50818 & 91016 & 303000 \\
\hline 10 & $\begin{array}{l}\text { Number of Internet } \\
\text { users }\end{array}$ & 8800000 & 12000000 & 12800000 & 21000000 & 26500000 & 27500000 \\
\hline 11 & $\begin{array}{l}\text { Development } \\
\text { of information } \\
\text { transfer network } \\
\text { (city) }\end{array}$ & 716 & 956 & 1182 & 1220 & 1223 & 1223 \\
\hline
\end{tabular}

(http://www.tci.ir/s40/page5.aspx?lang=Fa)

* Statistics of Iran's telecom network performance (comparative comparison for years 2005 to 2010, Iran ICT Corporation 2011 report)

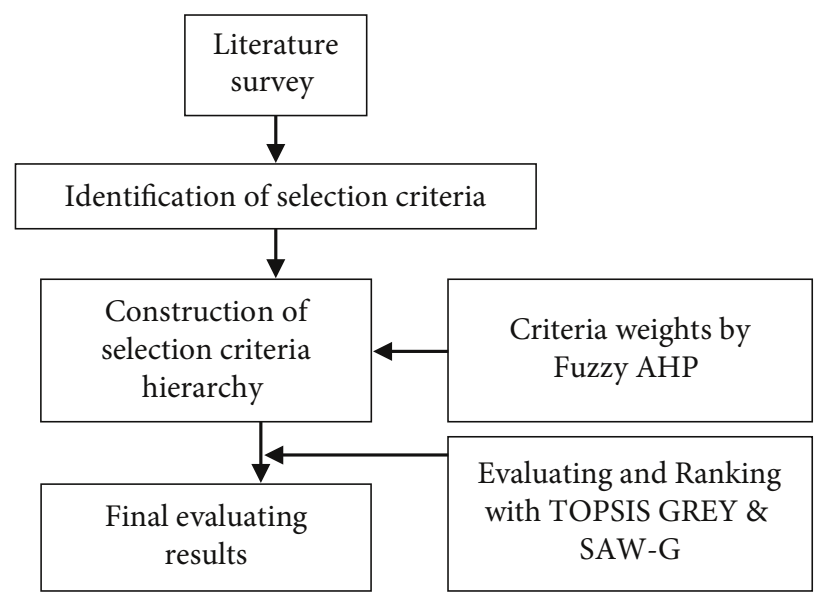

Fig. 1. Process of evaluating rural ICT centers (Rural Telecenters) in Iran 


\section{Literature review}

The recent researches about rural ICT centers are listed below:

Naik et al. (2012) argue that sustainability of these centers can be enhanced considerably if government services are embedded. Also, designing these telecenters with embedded G2C services would significantly improve effectiveness of their delivery and strengthen government information network, to foster inclusive growth.

Hashemkhani Zolfani et al. (2011) investigated economical and social Effects of rural telecenters in Iran. Their findings emphasized the strong positive effects of telecenters on education, training, culture and social aspects of rural communities.

Naik (2011) suggests an alternative model for rural telecenters, the e-governance embedded rural telecenters (EGERT), in which e-governance is an important service to be provided, and details the contentious issues clustered round the role of the government; the viability of partnership models with the private and NGO sectors; the institutional design for rural telecenters; the services to be rendered by the centers and the likely markets for them; the location of the centers and support in the form of infrastructure and manpower; and the technology to support the institutional design.

Mohamed et al. (2010) found that ICT is critical for sustainable development. In effect, many respondents agreed that due to the geographical separation and multifaceted nature of international sustainable development, it cannot be carried out without ICT's support. However, for ICT infrastructure to be translated into worthwhile returns, the organization must adopt knowledge-oriented ICT infrastructure. This is substantiated by ICT's role in decision quality, knowledge sharing, inter-organizational links, and the contribution to the resolution of the implicit conflict between sustainability and economic growth.

Dolo and Mackenzie (2010) employed a multi-method, user-centered approach to assess how participants make the most of Malian telecenter resources to meet needs, connect with others, and achieve goals. Their findings indicate while Malians as empowered change agents are impacted by deployments such as telecenters, they also affect and impact telecenters and create unanticipated new knowledge. Their study reveals the importance of recognizing the needed skills and identifying actors to promote successful community growth and adaptation. Although results indicate no direct correlation between technology use and wellbeing unless directly demonstrated, the use of the telecenter to connect with others was important to respondents. This research suggests a $U$-centric model, an alternative model for cooperative change that is cyclical, encourages ongoing evaluation, and effectively uses local resources.

Naivinit (2009) suggests that livelihood changes in specific areas, with a rise in self-esteem being one of the most noticeable changes. Moreover, financial opportunities, including career enhancement and product development, have expanded as a result of accessing CTs. In regard to gender, although it is found that there is only a small difference in financial opportunity between women and men, the findings point to more positive changes for women than men in terms of health enhancement and social connectedness, while men benefit slightly more in self-esteem and education.

Rao (2008) highlights the status of ICTs in India and their role in social development, and discusses the case of telecenters, their benefit and overview of current initiatives deals with 
the sustainability of telecenters and analyses the emerging scenario using Gartner's Hype Cycle. This study concludes that many ICT initiatives in India lack a comprehensive plan in addressing the target population, struggle to sustain due to insufficient infrastructure and are too ambitious as they are not equipped with appropriate technologies in serving the rural communities. To be successful, a telecenter model needs to be built upon the principles of multi-stakeholder partnership involving the government, private organizations for combining innovation, responsiveness with stability and public participation, and needs to include massive numbers of excluded people into the information world.

Kawooya (2004) reports on a case study of the school-based telecenter (SBT) model to assess appropriateness of the school-centered approach to universal access. The SBTs, established on a pilot basis, utilize VSAT-based technology to connect schools and neighboring communities to the internet. This paper documents the appropriateness of school-based access points for neighboring communities at two selected School Net-Uganda site schools. School-based access has policy implications for developing countries' approach to universal access and lifelong learning in the emerging knowledge society.

\section{Delivered and deliverable services in Iran's rural ICT centers (Hashemkhani}

Zolfani et al. 2011)

In 2005, the first telecenter of Iran was established in Gharnabad village located in Golestan province and we have perceived their significant progress since then. Some of deliverable services in these telecenters are as follows:

The most significant contribution to 'development' from telecenter networks emerge from computer based training. Supporting school curricula with appropriate ICT applications, computers for children, graphic design, hardware, web design and Internet are some of the more popular programs offered by telecenters. However, lack of standardization of computer based training has been an impediment to e-literacy programs.

Using information technology and accessing educational services have increasingly become easier and the presence of such telecenters can prepare a way for creating a knowledge center in rural community. Some deliverable educational services of those telecenters are as follows:

\subsection{Public training}

Sharing experiences, skills and expertise, identifying new or re-usable solutions for common problems, and sharing knowledge on diverse daily topics are some positive effects of telecenters on public training; some other aspects of public training derived from telecenters are noted as bellows:

- Training health related issues.

- Training agriculture.

- Training ranching.

- Training the computer, the internet.

- Other public training. 


\subsection{Classic training}

It is found that people in far-away communities are able to reach academic sources via the internet connection. To some extent, information sources on the internet replaced traveling to a library. This saved travel costs and time. Additionally, rural people did extend their knowledge and skills in computer and internet usage through training courses at telecenters. Telecentres provide communities accessing to the internet and are good places for knowledge sharing and academic education.

- Training illiterate and low literate ones (Literacy movement organization).

- Single course education such as apiculture, piscine culture, and things like that based on needs.

- Remote education of elementary, guidance and high school levels.

- Higher education universities and using virtual universities.

- Other classic educations.

\subsection{Special training}

Information communication technologies (ICTs) are fast becoming essential tools in the delivery of information, knowledge and education all over the world. The role of ICT-based telecenters in supporting educational and community development in both rich and poor countries is critical.

Some of the notable impacts of telecenters on social training can be summarized as below:

- Training dealing with natural events.

- Defense training.

- Women specific training.

- Special technical and professional training.

- Other special training.

\subsection{Cultural services}

As the structure of the world is evolving, the importance of being knowledgeable is getting more significance. Knowledge centered economy would replace traditional economy of the world. Will the villages have an independent economy for themselves, or they have to follow these evolutions? It seems that economy is similar in villages and cities and if the criterion is knowledge, we must provide suitable facilities for villagers to be able to access new economy through these telecenters. Today, with new phenomena such as electronic business, virtual production, credit card, electronic banking; it seems that the opportunities of advancement for villagers have increased. With this in mind, these telecenters can be helpful for the mentioned purposes. In the following, some instances of economic services of these centers are presented:

- Introducing agricultural, animal and other products in national and international markets.

- Performing banking and financial affairs through installing ATM in centers.

- Remote job finding and remote working.

- Electronic business.

- Other economic services. 


\subsection{Social services}

Although village councils have been developed, but there are no integrated offices or institutions to transfer their experiences to the next groups. These centers not only can facilitate the relationship between villagers and authorities, but also they can be applied as centers for holding council meetings in villagers' presence. Moreover, they can connect the villagers, council and state organizations to each other and present following services in social context:

- Holding the meetings of village council.

- Holding virtual conferences.

- Holding computer based elections.

- The base of associations and groups of NGO.

- Other social services.

\subsection{Governmental services}

These centers can be utilized as a connection point of electronic government with the villages so that the villagers can conduct their communication with governmental sectors through these centers. These centers can be exploited as a settlement place for the following governmental organizations that generally operate in villages:

- Virtual office of agricultural ministry.

- Virtual office of health ministry.

- Virtual office of education ministry.

- Virtual office of environment organization.

- Virtual office of agricultural bank.

- Virtual office of post bank.

- Virtual office of rural cooperative organization.

- Virtual office of other organizations related to villages.

Since any organization can not have an independent office in villages, placing all governmental organizations together in one place not only is cost effective but also encourages them to perform better by consultation and avoids duplication of work. Besides, at the moment many villages have university graduated persons, hence this center can attract them to work and they can work as employees or representatives of one or more of these state organizations. If these centers become successful, the demographic problem in villages can easily be solved and updated so that the authorities and decision makers can make plans based on real statistics for villagers.

\subsection{Other services}

Services provided by rural telecenters are diverse. These telecenters can develop like IT parks of country with the aim of a center for growth of rural IT. Also, they can act as educational centers or commercial service centers and like that. In the following, some of the services of these telecenters are described: 
- General services of internet such as: electronic post, video communication and conferences and internet telephone services, VOIP and fax.

- Coffee net services, ATM machines, rural IT parks, service kiosks.

- Firms and office information and commercial services.

- Medical information services.

- Other similar services.

Many other services can be delivered to villagers by this rural base and revolutionize their lives in economic, cultural, scientific, educational and social aspects. These telecenters can simultaneously have educational and commercial applications. They can be utilized as information and village news centers, rural research centers, village library, internet access centers, rural ISP internet servicing centers, the center for tourists' access to information and electronic services and finally the centers for coordinating the services and state organizations, if supported correctly, it can be a turning point in development of villages of Iran at the beginning of third millennium.

Seven important services presented in rural ICT centers are considered as a framework for evaluating as illustrated in Figure 2.

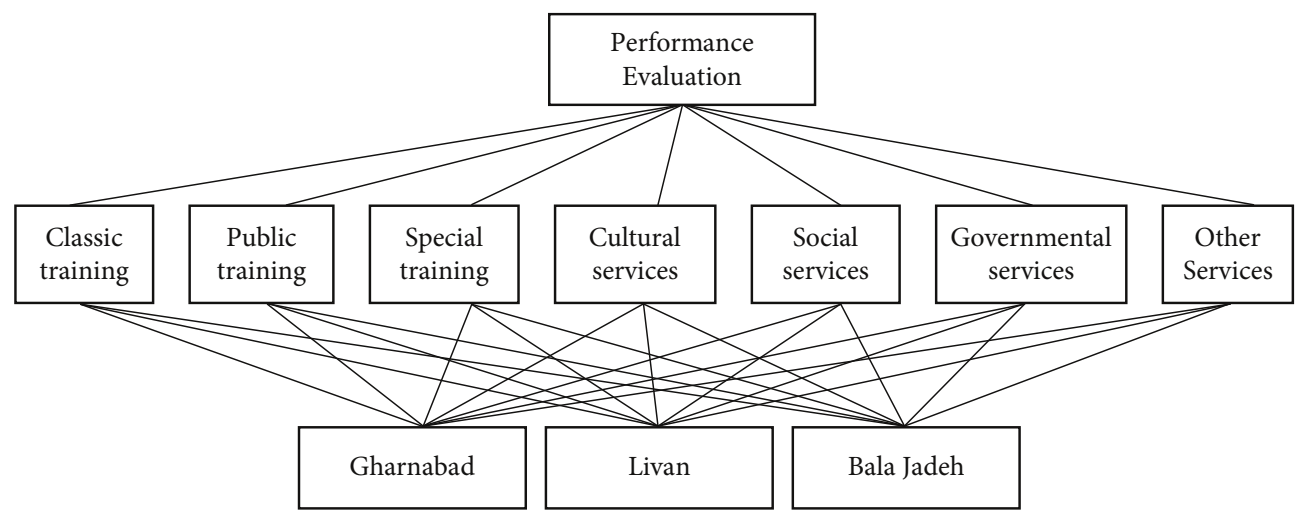

Fig. 2. The hierarchy structure of criteria

\section{Methodology}

Over the past decades the complexity of economic decisions has increased rapidly, thus highlighting the importance of developing and implementing sophisticated and efficient quantitative analysis techniques for supporting and aiding economic decision-making (Zavadskas, Turskis 2011). Multiple criteria analysis (MCA) provides a framework for breaking a problem into its constituent parts. MCA provides a means to investigate a number of alternatives in light of conflicting priorities. Over the last decade, a set of new MCDM methods have been developed. These new methods have been modified and applied to solve sophisticated practical and scientific problems. Solving modern decision making problems in most cases is based on integrated model of different approaches. There is a wide range of methods based on multicriteria utility theory: SAW (MacCrimon 1968); TOPSIS (Hwang, Yoon 1981); COPRAS 
(Zavadskas et al. 2010b); and other methods (Turskis, Zavadskas 2010; Zavadskas, Turskis 2010). Uncertain and vague future causes lots of difficulties for decision-makers. The multi criteria decision-making could be applied to assess different alternatives of future activities.

The best strategy can be selected from available scenarios and information. In strategic decisions, dealing with uncertainty, the values of criteria could be determined at intervals from pessimistic value to optimistic value. There is a wide range of methods based on multicriteria utility theory with grey numbers operations to the problems solution: TOPSIS-grey (Lin et al. 2008; Zavadskas et al. 2010a), SAW-G (Zavadskas et al. 2010a), COPRAS-G (Zavadskas et al. 2010b), ARAS-G (Turskis, Zavadskas 2010).

\subsection{Analytic hierarchy process}

Analytic hierarchy process (AHP), proposed by Thomas L. Saaty in 1971 (Saaty 1980), is able to solve the multiple criteria decision making problems. AHP utilizes three principles to solve problems (Aydogan 2011):

1. Structure of the hierarchy.

2. The matrix of pair wise comparison ratios, and

3. The method for calculating weights.

Analytic hierarchy process (AHP) is a powerful method to solve complex decision problems. Any complex problem can be decomposed into several sub-problems using AHP in terms of hierarchical levels where each level represents a set of criteria or attributes relative to each sub-problem. The AHP method is a multicriteria method of analysis based on an additive weighting process, in which several relevant attributes are represented through their relative importance. AHP has been extensively applied by academics and professionals, mainly in engineering applications involving financial decisions associated to non-financial attributes. During the past, there were 13 major conditions that have been discovered to well fit the utilization of AHP such as setting priorities, generating a set of alternatives, choosing a best policy alternatives, determining requirements, allocating resources, predicting outcomes, measuring performance, designing system, ensuring system stability, optimization, planning, resolving conflict, and risk assessment (Saaty 1980).

With this method, a complicated system is converted to a hierarchical system of elements. In each hierarchical level, pair-wise comparisons of $n$ elements are made by using a nominal scale and the value $m_{i j}$ is assigned to represent the judgment concerning the relative importance of decision element $\boldsymbol{e}_{i}$ over $\boldsymbol{e}_{j}$.

These comparisons compose a pair-wise comparison matrix $M=\left\{m_{i j}\right\}$. In order to find the weight of each element, or the score of each alternative, the priority vector (or eigenvector) $W=\left(w_{1}, w_{2}, \ldots, w_{n}\right)^{T}$ of this comparison matrix is calculated based on solving the equation (1):

$$
M w=\lambda_{\max } w, \quad \lambda_{\max } \geq n .
$$

It indicates that the eigenvector corresponding to the largest eigenvalue $\left(\lambda_{\max }\right)$ of the pair-wise comparisons matrix reflects the relative importance of the decision elements. This conventional AHP approach gives reasonably good approximation only when the decision-maker's preferences are consistent. However, the descriptions of linguistic variable 
(such as 'judgment' or 'preference') are usually vague and the verbal attitudes of decisionmaker's requirements on evaluation process always contain ambiguity and multiplicity of meaning. AHP is ineffective when applied to ambiguous problem. Thus, fuzzy sets could be incorporated with the pair-wise comparison, as an extension of AHP, to solve this kind of uncertainty (Lee 2010).

\subsection{Fuzzy AHP method}

In the proposed methodology, AHP with its fuzzy extension, namely fuzzy AHP, is applied to obtain more decisive judgments by prioritizing the market segment selection criteria and weighting them in the presence of vagueness. There are numerous fuzzy AHP applications in the literature that propose systematic approaches for selection of alternatives and justification of problem by using fuzzy set theory and hierarchical structure analysis (Efendigil et al. 2008; Önüt et al. 2010). DMs usually find it more convenient to express interval judgments than fixed value judgments due to the fuzzy nature of the comparison process (Bozdag et al. 2006). This study concentrates on a fuzzy AHP approach introduced by Chang (1996), in which triangular fuzzy numbers are preferred for pairwise comparison scale. Extent analysis method is selected for the synthetic extent values of the pairwise comparisons. Some papers published used the fuzzy AHP procedure based on extent analysis method and showed how it can be applied to selection problems (Cebeci, Ruan 2007; Kahraman et al. 2003, 2004). The outlines of the fuzzy sets and extent analysis method for fuzzy AHP are given below.

A fuzzy number is a special fuzzy set $F=\left\{\left(x, \mu_{F}(x), x \in R\right\}\right.$, where $x$ takes its values on the real line, $\mathrm{R}:-\infty \leq \mathrm{x} \leq \infty$ and $\mu_{F}(\mathrm{x})$ is a continuous mapping from $\mathrm{R}$ to the closed interval $[0,1]$. A triangular fuzzy number (TFN) expresses the relativestrength of each pair of elements in the same hierarchyand can be denoted as $\mathrm{M}=(\mathrm{l}, \mathrm{m}, \mathrm{u})$, where $\mathrm{l} \leq \mathrm{m} \leq \mathrm{u}$. The parameters $\mathrm{l}$; $\mathrm{m}$; $\mathrm{u}$; indicate the smallest possible value, the most promising value, and the largest possible value respectively in a fuzzy event.

Triangular type membership function of M fuzzy number can be described as in Equation 1 .

$$
\mu_{M}(x)=\left\{\begin{array}{cc}
0 & x \prec l \\
(x-l) /(m-l) & l \leq x \leq m \\
(u-x) /(u-m) & m \leq x \leq u \\
0 & x \succ u
\end{array} .\right.
$$

A linguistic variable is a variable whose values are expressed in linguistic terms (Önüt et al. 2008). The concept of a linguistic variable is very useful in dealing with situations, which are too complex or not well defined to be reasonably described in conventional quantitative expressions (Zadeh 1965).

In this study, the linguistic variables that are utilized in the model can be expressed in positive TFNs for each criterion as in Figure 3. 


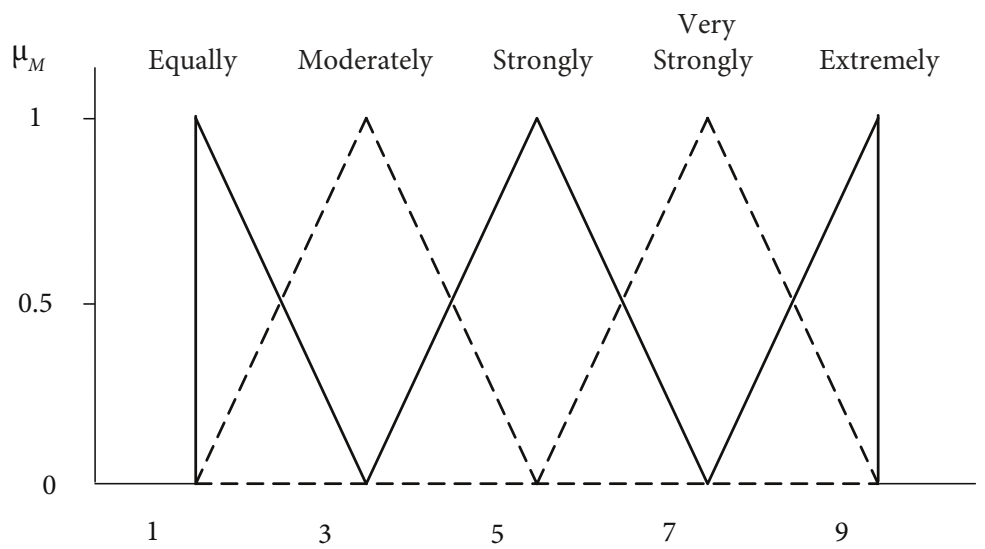

Fig. 3. Linguistic variables for the importance weight of each criterion

The linguistic variables matching TFNs and the corresponding membership functions are provided in Table 2. Proposed methodology employs a Likert Scale of fuzzy numbers starting from $\tilde{1}$ to $\tilde{9}$ symbolize with tilde $(\sim)$ for the fuzzy AHP approach. Table 2 depicts AHP and fuzzy AHP comparison scale considering the linguistic variables that describes the importance of criteria and alternatives to improve the scaling scheme for the judgment matrices.

Table 2. Linguistic variables describing criteria's weights and rating values

\begin{tabular}{|c|c|c|c|c|}
\hline $\begin{array}{l}\text { Linguistic scale for } \\
\text { importance }\end{array}$ & $\begin{array}{c}\text { Fuzzy } \\
\text { numbers for } \\
\text { fuzzy AHP }\end{array}$ & Membership function & Domain & $\begin{array}{c}\text { Triangular fuzzy } \\
\text { scale } \\
(\mathrm{l}, \mathrm{m}, \mathrm{u})\end{array}$ \\
\hline Just equal & & & & $(1.0,1.0,1.0)$ \\
\hline Equal importance & $\tilde{1}$ & $\mu_{M}(x)=(3-x) /(3-1)$ & $1 \leq x \leq 3$ & $(1.0,1.0,3.0)$ \\
\hline \multirow[t]{2}{*}{$\begin{array}{l}\text { Weak importance } \\
\text { of one over another }\end{array}$} & $\tilde{3}$ & $\mu_{M}(x)=(x-1) /(3-1)$ & $1 \leq x \leq 3$ & $(1.0,3.0,5.0)$ \\
\hline & & $\mu_{M}(x)=(5-x) /(5-3)$ & $3 \leq x \leq 5$ & \\
\hline \multirow[t]{2}{*}{$\begin{array}{l}\text { Essential or strong } \\
\text { importance }\end{array}$} & $\tilde{5}$ & $\mu_{M}(x)=(x-3) /(5-3)$ & $3 \leq x \leq 5$ & $(3.0,5.0,7.0)$ \\
\hline & & $\mu_{M}(x)=(7-x) /(7-5)$ & $5 \leq x \leq 7$ & \\
\hline \multirow[t]{2}{*}{$\begin{array}{l}\text { Very strong } \\
\text { importance }\end{array}$} & $\tilde{7}$ & $\mu_{M}(x)=(x-5) /(7-5)$ & $5 \leq x \leq 7$ & $(5.0,7.0,9.0)$ \\
\hline & & $\mu_{M}(x)=(9-x) /(9-7)$ & $7 \leq x \leq 9$ & \\
\hline Extremely preferred & $\tilde{9}$ & $\mu_{M}(x)=(x-7) /(9-7)$ & $7 \leq x \leq 9$ & $(7.0,9.0,9.0)$ \\
\hline \multicolumn{3}{|c|}{$\begin{array}{l}\text { If factor } i \text { has one of the above numbers assigned } \\
\text { to it when compared to factor } j \text {, then } j \text { has the reciprocal value } \\
\text { when compared with } i\end{array}$} & \multicolumn{2}{|c|}{$\begin{array}{l}\text { Reciprocals of above } \\
M_{1^{-1}} \approx\left(1 / u_{1}, 1 / m_{1}, 1 / l_{1}\right)\end{array}$} \\
\hline
\end{tabular}


By using TFNs via pairwise comparison, the fuzzy judgment matrix $\tilde{A}\left(a_{i j}\right)$ can be expressed mathematically as in Equation 2:

$$
\tilde{A}=\left\{\begin{array}{llllll}
1 & \tilde{a}_{12} & \tilde{a}_{13} & \ldots & \tilde{a}_{1(n-1)} & \tilde{a}_{1 n} \\
\tilde{a}_{21} & 1 & \tilde{a}_{23} & \ldots & \left.\tilde{a}_{2(n-1)}\right) & \tilde{a}_{2 n} \\
\vdots & \vdots & \vdots & \vdots & \vdots & \vdots \\
\vdots & \vdots & \vdots & \cdots & \vdots & \vdots \\
\tilde{a}_{(n-1) 1} & \tilde{a}_{(n-1) 2} & \tilde{a}_{(n-1) 3} & \cdots & 1 & \tilde{a}_{(n-1) n} \\
\tilde{a}_{n 1} & \tilde{a}_{n 2} & \tilde{a}_{n 3} & \cdots & \tilde{a}_{n(n-1)} & 1
\end{array} .\right.
$$

The judgment matrix $\tilde{A}$ is an $n \times n$ fuzzy matrix containing fuzzy numbers $\tilde{a}_{i j}$.

$$
\tilde{a}_{i j}=\left\{\begin{array}{l}
1, i=j \\
\tilde{1}, \tilde{3}, \tilde{5}, \tilde{7}, \tilde{9} \text { or } \cdots \tilde{1}^{-1}, \tilde{3}^{-1}, \tilde{5}^{-1}, \tilde{7}^{-1}, \tilde{9}^{-1}, i \neq j
\end{array} .\right.
$$

Let $X=\left\{x_{1}, x_{2}, \ldots x_{n}\right\}$ be an object set, whereas $U=\left\{u_{1}, u_{2}, \ldots u_{n}\right\}$ is a goal set. According to fuzzy extent analysis, the method can be performed with respect to each object for each corresponding goal, $g_{i}$, resulting in m extent analysis values for each object, given as $M_{g i}^{1}, M_{g i}^{2}, \ldots, M_{g i}^{n}, i=1,2, \ldots, n$ where all the $M_{g i}^{j}(j=1,2, \ldots, m)$ are TFNs representing the performance of the object $x_{i}$ with regard to each goal $u_{j}$. The steps of Chang's extent analysis (1996) can be detailed as follows (Kahraman et al. 2003, 2004):

Step 1: The fuzzy synthetic extent value with respect to the $i$ th object is defined as:

$$
S_{i}=\sum_{j=1}^{m} M_{g i}^{j} \otimes\left[\sum_{i=1}^{n} \sum_{j=1}^{m} M_{g i}^{j}\right]^{-1}
$$

To obtain $\sum_{j=1}^{m} M_{g i}^{j}$, perform the fuzzy addition operation $\mathrm{m}$ extent analysis values for a particular matrix such that operation m extent analysis values for a particular matrix such that

$$
\sum_{j=1}^{m} M_{g i}^{j}=\left(\sum_{j=1}^{m} l_{j}, \sum_{j=1}^{m} m_{j}, \sum_{j=1}^{m} u_{j}\right)
$$

and obtain $\left[\sum_{i=1}^{n} \sum_{j=1}^{m} M_{g i}^{j}\right]^{-1}$, perform the fuzzy addition operation of $M_{g i}^{j}(j=1,2, \ldots, m)$ values and such that

$$
\sum_{i=1}^{n} \sum_{j=1}^{m} M_{g i}^{j}=\left(\sum_{i=1}^{n} l_{i}, \sum_{i=1}^{n} m_{i}, \sum_{i=1}^{n} u_{i}\right)
$$


and then compute the inverse of the vector in Equation 6 such that

$$
\left[\sum_{i=1}^{n} \sum_{j=1}^{m} M_{g i}^{j}\right]^{-1}=\left(\frac{1}{\sum_{i=1}^{n} u_{i}}, \frac{1}{\sum_{i=1}^{n} m_{i}}, \frac{1}{\sum_{i=1}^{n} l_{i}}, .\right.
$$

Step 2: The degree of possibility of $M_{2} \geq M_{1}$ is defined as:

$$
V\left(M_{2} \geq M_{1}\right)=\sup \left[\min \left(\mu_{M_{1}}(x), \mu_{M_{2}}(y)\right)\right] \text {, }
$$

and can be equivalently expressed as follows:

$$
V\left(M_{2} \geq M_{1}\right)=h g t\left(M_{1} \cap M_{2}\right)=\mu_{M_{2}}(d)=\left\{\begin{array}{l}
1, \text { if }\left(m_{2} \geq m_{1}\right), \\
0, \text { if }\left(l_{1} \geq u_{2}\right), \\
\frac{l_{1}-u_{2}}{\left(m_{2}-u_{2}\right)-\left(m_{1}-l_{1}\right)}, \text { otherwise, }
\end{array}\right.
$$

where $d$ is the ordinate of the highest intersection point $D$ between $\mu_{M_{1}}$ and $\mu_{M_{2}}$ (see Figure 4). To compare $M_{1}$ and $M_{2}$, both the values of $V\left(M_{1} \geq M_{2}\right)$ and $V\left(M_{2} \geq M_{1}\right)$ are required.

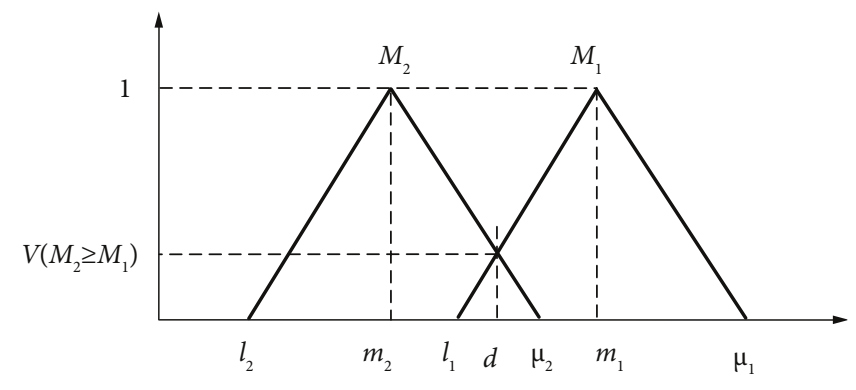

Fig. 4. Intersection point " $d$ " between two fuzzy numbers $M_{1}$ and $M_{2}$

Step 3: The degree possibility of a convex fuzzy number to be greater than $k$ convex fuzzy numbers $M_{i}(i=1,2, \ldots, k)$ can be defined by Equation 10 .

$V\left(M \geq M_{1}, M_{2} \ldots M_{K}\right)=V\left[M \geq M_{1}\right]$ and, $V\left[M \geq M_{2}\right]$ and ...and, $V\left[M \geq M_{k}\right]=\min \left(V\left[M \geq M_{i}\right], i=1,2, \ldots, k .(11)\right.$

Assume that:

$$
d^{\prime}\left(A_{i}\right)=\min \left(S_{i} \geq S_{k}\right)
$$


For $k=1,2, \ldots, n ; k \neq i$. Then, the weight vector is given by as in Equation 12:

$$
W^{\prime}=\left(d^{\prime}\left(A_{1}\right), d^{\prime}\left(A_{2}\right), \ldots d^{\prime}\left(A_{n}\right)\right)^{T},
$$

where $A_{i}(i=1,2, \ldots n)$ has $n$ elements.

Step 4: The normalized weight vectors are defined as:

$$
W=\left(d\left(A_{1}\right), d\left(A_{2}\right), \ldots d\left(A_{n}\right)\right)^{T},
$$

where $W$ is a non fuzzy number.

\subsection{SAW-G method}

The Simple Additive Weighting method with grey number can be described as the following steps (Zavadskas et al. 2010a).

Step 1: Selecting the set of the most important criteria, describing the alternatives.

Step 2: Constructing the decision-making matrix $\otimes X$.

Step 3: Normalization process for getting comparable scales. The normalized values are calculated as follows:

If $\min x_{i j}$ is preferable

$$
\begin{gathered}
\bar{w}_{i j}=\frac{w_{i j}}{\max w_{i j}}, \bar{b}_{i j}=\frac{b_{i j}}{\max w_{i j}} ; \\
\bar{w}_{i j}=\frac{\min b_{i j}}{w_{i j}}, \bar{b}_{i j}=\frac{\min b_{i j}}{b_{i j}} .
\end{gathered}
$$

$$
\otimes x=\left(\begin{array}{l}
{\left[\bar{w}_{11} ; \bar{b}_{12}\right]\left[\bar{w}_{12} ; \bar{b}_{12}\right] \ldots \ldots . .\left[\bar{w}_{1 m} ; \bar{b}_{1 m}\right]} \\
{\left[\bar{w}_{21} ; \bar{b}_{12}\right]\left[\bar{w}_{22} ; \bar{b}_{22}\right] \ldots \ldots . .\left[\bar{w}_{2 m} ; \bar{b}_{2 m}\right]} \\
\because \cdot \\
{\left[\bar{w}_{n 1} ; \bar{b}_{n 1}\right]\left[\bar{w}_{n 2} ; \bar{b}_{n 2}\right] \ldots \ldots .\left[\bar{w}_{n m} ; \bar{b}_{n m}\right]}
\end{array}\right) .
$$

Step 4: Determining weights of the criteria $q_{i}$.

Step 5: Weighted - normalized decision-making matrix is obtained according to equation (18):

$$
\otimes \widehat{x}_{i j}=\otimes \bar{x}_{i j} \cdot q_{j} ; \hat{w}_{i j}=\bar{w}_{i j} \cdot q_{i j} ; \widehat{b}_{i j}=\bar{b}_{i j} \cdot q_{j},
$$

where $q_{i}$ is the weight of the $j$-th attribute.

Step 6: The next step is to calculate optimality criterion $L$ which is determined as maximal value of $L_{i}$ :

$$
L_{i}=\frac{1}{n} \sum_{j=1}^{m} \frac{\bar{w}_{j}+\bar{b}_{j}}{2} . \quad \bar{w}_{i j}=\frac{w_{i j}}{\max w_{i j}}, \bar{b}_{i j}=\frac{b_{i j}}{\max w_{i j}} .
$$

Step 7: Optimal alternative is determined as maximal value of $L_{i}$. 


\subsection{TOPSIS Grey}

The TOPSIS method was developed by Hwang and Yoon (1981). TOPSIS method belongs to MCDM (Multi-criteria decision-making method) group and identifies solutions from a finite set of alternatives based upon simultaneous minimization of distance from an ideal point and maximization of distance from a negative ideal point. TOPSIS can incorporate relative weights of criteria. The only subjective input needed is weights. Lin et al. (2008) developed TOPSIS method with grey number operations to the problem solution with uncertain information. Zavadskas et al. (2010a, 2010b) used TOPSIS method with grey numbers operations to risk assessment of construction project for contractor selection for constructions works.

The TOPSIS method is one of the best described mathematically and not simple for practical using. Lin et al. (2008) proposed the model of TOPSIS method with attributes values determined at intervals that includes the following steps:

Step 1: Selecting the set of the most important attributes, describing the alternatives.

Step 2: Constructing the decision-making matrix $\otimes X$. Grey number matrix $\otimes X$ can be defined as:

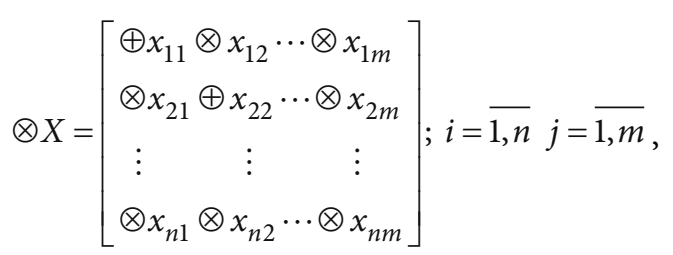

where $\otimes x_{i j}$ denotes the grey evaluations of the $i$-th alternative with respect to the $j$-th attribute; $\left[\otimes x_{i 1}, \otimes x_{i 2}, \ldots, \otimes x_{i m}\right]$ is the grey number evaluation series of the $i$-th alternative.

Step 3: Construct the normalized grey decision matrices. The normalized values of maximizing attributes are calculated as:

$$
\otimes \bar{x}_{i j, b}=\frac{\otimes x_{i j}}{\max _{i}\left(b_{i j}\right)}=\left(\frac{w_{i j}}{\max _{i}\left(b_{i j}\right)}, \frac{b_{i j}}{\max _{i}\left(b_{i j}\right)}\right) .
$$

The normalized values of minimizing attributes are calculated by Lin et al. (2008):

$$
\otimes \bar{x}_{i j, w}=1-\frac{\otimes x_{i j}}{\max _{i}\left(b_{i j}\right)}=\left(1-\frac{b_{i j}}{\max _{i}\left(b_{i j}\right)} ; 1-\frac{w_{i j}}{\max _{i}\left(b_{i j}\right)}\right) .
$$

Step 4: Determining weights of the criteria $q_{j}$.

Step 5: Construct the grey weighted normalized decision-making matrix.

Step 6: Determine the positive and negative ideal alternatives for each decision-maker. The positive ideal alternative $\mathrm{A}^{+}$, and the negative ideal alternative $\mathrm{A}^{-}$can be defined as:

$$
A^{+}=\left\{\left(\max _{i} b_{i j} \mid j \in J\right),\left(\min _{i} w_{i j} \mid j \in J^{\prime}\right) \mid\{i \in n\}=\left[x_{1}^{+}, x^{+}, \ldots \ldots x_{m}{ }^{+}\right]\right.
$$

and

$$
A^{-}=\left\{\left(\min _{i} w_{i j} \mid j \in J\right),\left(\max _{i} b_{i j} \mid j \in J^{\prime}\right) \mid i \in n\right\}=\left[x_{1}^{-}, x_{2}{ }^{-}, \ldots . . x_{m}{ }^{-}\right] .
$$


Step 7: Calculate the separation measure from the positive and negative ideal alternatives, $d_{i}^{+}$and $d_{i}^{-}$, for the group. There are two sub-steps to be considered: the first one concerns the separation measure for individuals; the second one aggregates their measures for the group.

Calculate the measures from the positive and negative ideal alternatives individually. For decision-maker $\mathrm{k}$, the separation measures from the positive ideal alternative $d_{i}^{+}$and negative ideal alternative $d_{i}^{-}$are computed through weighted grey number as:

$$
\begin{aligned}
& d_{i}^{+}=\left\{\frac{1}{2} \sum_{j=1}^{m} q_{j}\left[\left|x_{j}^{+}-\bar{w}_{i j}\right|^{p}+\left|x_{j}^{+}-\bar{b}_{i j}\right| p\right]\right\}^{\frac{1}{p}}, \\
& d_{i}^{-}=\left\{\frac{1}{2} \sum_{j=1}^{m} q_{j}\left[\left|x_{j}^{-}-\bar{w}_{i j}\right|^{p}+\left|x_{j}^{-}-\bar{b}_{i j}\right| p\right]\right\}^{\frac{1}{p}} .
\end{aligned}
$$

In equations (19) and (20), for $p \geq 1$ and integer, $q_{j}$ is the weight for the attribute $j$, which can be determined by attribute weight determination methods. If $\mathrm{p}=2$, then the metric is a weighted grey number Euclidean distance function. Equations (25) and (26) will be as follows:

$$
\begin{aligned}
& d_{i}^{+}=\sqrt{\frac{1}{2} \sum_{j=1}^{m} q_{i}\left[\left|x_{j}^{k^{+}}-\bar{w}_{i j}^{k}\right|^{2}+\left|x_{j}^{k_{j}^{+}}-\bar{b}_{i j}^{k}\right|^{2}\right]}, \\
& d_{i}^{-}=\sqrt{\frac{1}{2} \sum_{j=1}^{m} q_{j}\left[\left|x_{j}^{k^{-}}-\bar{w}_{i j}^{k}\right|^{2}+\left|x_{j}^{k^{-}}-\bar{b}_{i j}^{k}\right|^{2}\right]} .
\end{aligned}
$$

Step 8: Calculate the relative closeness $C_{i}^{+}$, to the positive ideal alternative for the group. The aggregation of relative closeness for the $i$-th alternative with respect to the positive ideal alternative for the group can be expressed as:

$$
C_{i}^{+}=\frac{d_{i}^{-}}{d_{i}^{+}+d_{i}^{-}},
$$

where $0 \leq C_{i}^{+} \leq 1$. The larger the index value is, the better the evaluation of alternative will be.

Step 9: Rank the preference order. A set of alternatives now can be ranked by the descending order of the value of $C_{i}^{+}$.

\section{Results}

\subsection{Using FAHP method for criteria prioritization}

Fuzzy AHP is used for determining the weights of main and sub-criteria. For pair wise comparison decision making in FAHP, a questionnaire was utilized to get experts' point of view. The experts are the senior managers in the three mentioned telecenters with the following background; all information about the experts of present study is shown in Table 3.

Paired comparison matrix is a matrix which is formed using experts' viewpoints as it is illustrated in Table 4. FAHP method is then applied for prioritizing. 
After processing the fuzzy data, the final weights of criteria are obtained. According to each indicator's weight which is shown in Table 5, public training and cultural services are the most important criteria of all.

Table 3. Background information of experts

\begin{tabular}{|c|c|c|c|c|c|}
\hline Variable & Items & NO & Variable & Items & $\mathrm{NO}$ \\
\hline \multirow{3}{*}{$\begin{array}{l}\text { 1. Education } \\
\text { background }\end{array}$} & Bachelor & 2 & \multirow[t]{3}{*}{ 3. Gender } & Male & 8 \\
\hline & Master & 5 & & Female & 2 \\
\hline & $\mathrm{PhD}$ & 3 & & & \\
\hline \multirow[t]{2}{*}{ 2. Groups } & Government & 4 & \multirow[t]{2}{*}{ 4. Age } & $31-40$ & 6 \\
\hline & Researcher & 6 & & $41-50$ & 4 \\
\hline
\end{tabular}

Table 4. Fuzzy pair-wise comparison matrix

\begin{tabular}{cccccccc}
\hline & $\mathrm{C} 1$ & $\mathrm{C} 2$ & $\mathrm{C} 3$ & $\mathrm{C} 4$ & $\mathrm{C} 5$ & $\mathrm{C} 6$ & $\mathrm{C} 7$ \\
\hline $\mathrm{C} 1$ & $1,1,1$ & $1,1,3$ & $1,3,5$ & $1 / 3,1,1$ & $1,3,5$ & $3,5,7$ & $5,7,9$ \\
\hline $\mathrm{C} 2$ & $1 / 3,1,1$ & $1,1,1$ & $1,3,5$ & $1 / 5,1 / 3,1$ & $1 / 5,1 / 3,1$ & $1,3,5$ & $3,5,7$ \\
\hline $\mathrm{C} 3$ & $1 / 5,1 / 3,1$ & $1 / 5,1 / 3,1$ & $1,1,1$ & $1 / 9,1 / 7,1 / 5$ & $1 / 7,1 / 5,1 / 3$ & $1 / 3,1,1$ & $1,1,1$ \\
\hline $\mathrm{C} 4$ & $1,1,3$ & $1,3,5$ & $5,7,9$ & $1,1,1$ & $1,1,3$ & $1,1,3$ & $5,7,9$ \\
\hline $\mathrm{C} 5$ & $1 / 5,1 / 3,1$ & $1,3,5$ & $3,5,7$ & $1 / 3,1,1$ & $1,1,1$ & $1,1,3$ & $3,5,7$ \\
\hline $\mathrm{C} 6$ & $1 / 7,1 / 5,1 / 3$ & $1 / 5,1 / 3,1$ & $1,1,3$ & $1 / 3,1,1$ & $1 / 3,1,1$ & $1,1,1$ & $1,1,3$ \\
\hline $\mathrm{C} 7$ & $1 / 9,1 / 7,1 / 5$ & $1 / 7,1 / 5,1 / 3$ & $1,1,1$ & $1 / 9,1 / 7,1 / 5$ & $1 / 7,1 / 5,1 / 3$ & $1 / 3,1,1$ & $1,1,1$ \\
\hline
\end{tabular}

Table 5. The final weights of criteria

\begin{tabular}{lccccccc}
\hline Criteria & C1 & C2 & C3 & C4 & C5 & C6 & C7 \\
\hline Final weights & 0.25 & 0.19 & 0.008 & 0.25 & 0.22 & 0.08 & 0.002 \\
\hline
\end{tabular}

The description of the abbreviations used in Tables 3 and 4 are presented as below; C1: Public Training, C2: Classic Training, C3: Special Training, C4: Cultural Services, C5: Social Services, C6: Governmental Services and C7: Other Services.

\subsection{Evaluation of rural ICT centers by SAW-G and TOPSIS Grey}

Ranking of alternatives by SAW-G and TOPSIS Grey technique and the weights that are calculated in last stage (Fuzzy AHP), is performed.

The initial decision-making matrix with values determined at intervals is presented in Table 6. In Table 6 given notations $q_{j}$ are the criteria weights and $A_{1}, \ldots A_{5}$ are alternatives. In this table the group of experts evaluated each candidate according to each criterion. The evaluation has done on a scale from 1 to 9 , where 9 meant "very important" and 1 "not important at all". 
Table 6. Initial decision-making matrix with values

\begin{tabular}{|c|c|c|c|c|c|c|c|c|c|c|c|c|c|c|}
\hline \multicolumn{7}{|c|}{ Alternatives } & \multicolumn{8}{|c|}{ Criteria } \\
\hline & \multicolumn{2}{|c|}{$\otimes x_{1}$} & \multicolumn{2}{|c|}{$\otimes x_{2}$} & \multicolumn{2}{|c|}{$\otimes x_{3}$} & \multicolumn{2}{|c|}{$\otimes x_{4}$} & \multicolumn{2}{|c|}{$\otimes x_{5}$} & \multicolumn{2}{|c|}{$\otimes x_{6}$} & \multicolumn{2}{|c|}{$\otimes x_{7}$} \\
\hline Optimum & \multicolumn{2}{|c|}{$\max$} & \multicolumn{2}{|c|}{$\max$} & \multicolumn{2}{|c|}{$\max$} & \multicolumn{2}{|c|}{$\max$} & \multicolumn{2}{|c|}{$\max$} & \multicolumn{2}{|c|}{$\max$} & \multicolumn{2}{|c|}{$\max$} \\
\hline$A_{1}$ & 5 & 6 & 7 & 7.5 & 7 & 8 & 7 & 7.5 & 7 & 8 & 8 & 9 & 7 & 8 \\
\hline$A_{2}$ & 8 & 9 & 8 & 9 & 7.5 & 8 & 8 & 9 & 7.5 & 8 & 8 & 9 & 7.5 & 8 \\
\hline$A_{3}$ & 7 & 8 & 7 & 8 & 7.5 & 8 & 7.5 & 8 & 8 & 9 & 8 & 9 & 8 & 9 \\
\hline Optimal value & \multicolumn{2}{|c|}{9} & \multicolumn{2}{|c|}{9} & \multicolumn{2}{|c|}{8} & \multicolumn{2}{|c|}{9} & \multicolumn{2}{|c|}{9} & \multicolumn{2}{|c|}{9} & \multicolumn{2}{|c|}{9} \\
\hline
\end{tabular}

Table 7. Normalized decision-making matrix

\begin{tabular}{|c|c|c|c|c|c|c|c|c|c|c|c|c|c|}
\hline \multicolumn{7}{|c|}{ Alternatives } & \multicolumn{7}{|c|}{ Normalized values of criteria } \\
\hline & \multicolumn{2}{|c|}{$\otimes x_{1}$} & \multicolumn{2}{|c|}{$\otimes x_{2}$} & \multicolumn{2}{|c|}{$\otimes x_{3}$} & \multicolumn{2}{|c|}{$\otimes x_{4}$} & \multicolumn{2}{|c|}{$\otimes x_{5}$} & \multicolumn{2}{|c|}{$\otimes x_{6}$} & $\otimes x_{7}$ \\
\hline & \multicolumn{2}{|c|}{$\bar{w}_{1} \bar{b}_{1}$} & \multicolumn{2}{|c|}{$\bar{w}_{2} \bar{b}_{2}$} & \multicolumn{2}{|c|}{$\overline{w_{3} b_{3}}$} & \multicolumn{2}{|c|}{$\overline{w_{4} b_{4}}$} & \multicolumn{2}{|c|}{$\overline{w_{5} b_{5}}$} & \multicolumn{2}{|c|}{$\overline{w_{6} b_{6}}$} & $\overline{w_{7} b_{7}}$ \\
\hline & \multicolumn{2}{|c|}{$\max$} & \multicolumn{2}{|c|}{$\max$} & \multicolumn{2}{|c|}{$\max$} & \multicolumn{2}{|c|}{$\max$} & \multicolumn{2}{|c|}{$\max$} & \multicolumn{2}{|c|}{$\max$} & $\max$ \\
\hline Weights $q_{j}$ & 0.25 & 0.25 & 0.19 & 0.19 & 0.008 & 0.008 & 0.25 & 0.25 & 0.22 & 0.22 & 0.08 & 0.08 & $0.002 \quad 0.002$ \\
\hline$A_{1}$ & 0.555 & 0.667 & 0.777 & 0.833 & 0.875 & 1 & 0.777 & 0.833 & 0.777 & 0.888 & 0.888 & 1 & $0.777 \quad 0.888$ \\
\hline$A_{2}$ & 0.888 & 1 & 0.888 & 1 & 0.937 & 1 & 0.888 & 1 & 0.833 & 0.888 & 0.888 & 1 & 0.833 \\
\hline$A_{3}$ & 0.777 & 0.888 & 0.777 & 0.888 & 0.937 & 1 & 0.833 & 0.888 & 0.888 & 1 & 0.888 & 1 & 0.888 \\
\hline
\end{tabular}

Based on formula 15 normalize values of each criterion is obtained in Table 7 based on information of Table 6 . The results of the calculation for each alternative are presented in Table 8.

According to the SAW-G and TOPSIS Grey and the weight that calculated with FAHP methods the order of alternatives ranks is: $A_{2} \succ A_{3} \succ A_{1}$.

Table 8. Weighted-normalized decision-making matrix

\begin{tabular}{|c|c|c|c|c|c|c|c|c|c|c|}
\hline \multicolumn{3}{|c|}{ Alternatives } & \multicolumn{4}{|c|}{ Weighted-normalized values of criteria } & \multirow{3}{*}{ TOPSIS grey } & \multirow{3}{*}{\multicolumn{2}{|c|}{ SAW-G }} & \\
\hline$\otimes x_{1}$ & $\otimes x_{2}$ & $\otimes x_{3}$ & $\otimes x_{4}$ & $\otimes x_{5}$ & & \multirow[b]{2}{*}{$\otimes x_{5}$} & & & & \\
\hline$\otimes x_{1-1}$ & $\otimes x_{1-2}$ & $\otimes x_{1-3}$ & $\otimes x_{2}$ & $\otimes x_{3}$ & $\otimes x_{4}$ & & & & & \\
\hline $\bar{w}_{1-1} b_{1-1}$ & $\bar{w}_{1-2} \bar{b}_{1-2}$ & $\bar{w}_{1-3} \bar{b}_{1-3}$ & $\bar{w}_{2} \bar{b}_{2}$ & $\bar{w}_{3} \bar{b}_{3}$ & $\bar{w}_{4} \bar{b}_{4}$ & $\bar{w}_{5} \bar{b}_{5}$ & $a^{+}$ & $\begin{array}{l}\text { है } \\
\text { ๕ี }\end{array}$ & $L$ & 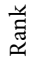 \\
\hline$A_{1} 0.1380 .166$ & 0.1470 .158 & 0.0070 .008 & 0.170 .195 & 50.1940 .2080 & 0.0710 .08 & 0.0010 .0010 & 0.10460 .07240 .330 & 3 & 0.110 & 3 \\
\hline$A_{2} \quad 0.2220 .25$ & 0.1680 .19 & 0.0070 .008 & 0.1830 .195 & 50.2220 .250 & 0.0710 .08 & 0.0010 .0010 & 0.10420 .06730 .7645 & 1 & 0.132 & 1 \\
\hline$A_{3} \quad 0.1940 .222$ & 0.1470 .168 & 0.0070 .008 & 0.1950 .22 & 0.2080 .2220 & 0.0710 .08 & 0.0010 .0020 & 0.09560 .04710 .7131 & 2 & 0.124 & 2 \\
\hline$A^{+} \quad 0.250 .138$ & 0.190 .147 & 0.0080 .007 & $0.22 \quad 0.17$ & 0.250 .194 & 0.080 .071 & 10.0020 .001 & & & & \\
\hline$A^{-} 0.1380 .25$ & 0.1470 .19 & 0.0070 .008 & $0.17 \quad 0.22$ & 0.1940 .250 & 0.0710 .08 & 0.00120 .002 & & & & \\
\hline
\end{tabular}




\section{Conclusion}

In this study Fuzzy AHP, SAW-G and TOPSIS Grey are applied for performance evaluation of rural ICT centers (Telecenters) in Iran and for this aim three telecenters were selected as a case study in Golestan Province in north of Iran where the first telecenter in Iran was established. The second telecenter in Iran was also established in Golestan Province. Each work needs time to bring about positive changes and based on our study, we have concluded that telecenters need at least three years to develop their predetermined purposes in rural areas. Gharnabad, Livan and Bala Jadeh villages selected for this study were established more than three years ago and all of them have their own websites. Important criteria for this study have been identified via previous researches which are public training, classic training, special training, cultural services, social services, governmental services and other services. Results of Fuzzy AHP show that public training and cultural services are more important criteria for the evaluating of rural ICT centers since knowledge domain in villages is lower than cities these years and these centers will help to increase people's knowledge level in villages. After that cultural services has gained the third priority and social services, governmental services and finally other services don't seem to have very great importance for villages these days but it can be predicted that as people's knowledge level in villages improves, these two criteria are likely to gain higher significance in near future. The results of SAW-G and TOPSIS Grey method are the same and Gharnabad telecenter has been evaluated as the best center, Livan telecenter was placed at the second and Bala Jadeh telecenter was the last. Developing knowledge in all areas of each country is very important and rural ICT centers have a key role in this sector. This study can be used as an evaluation framework for rural ICT centers in Iran and other countries.

\section{References}

Aydogan, E. K. 2011. Performance measurement model for Turkish aviation firms using the rough-AHP and TOPSIS methods under fuzzy environment, Expert Systems with Applications 38(4): 3992-3998. http://dx.doi.org/10.1016/j.eswa.2010.09.060

Best, M.; Kumar, R. 2008. Sustainability failures of rural telecenters: challenges from the sustainable access in rural India (sari) project, Information Technologies and International Development 4(4):31-45. http://dx.doi.org/10.1162/itid.2008.00025

Bhatnagar, S. 2009. Unlocking e-Government Potential: Concepts, Cases and Practical Insights. New Delhi: Sage.

Bozdag, C. E.; Kahraman, C.; Ruan, D. 2006. Fuzzy group decision making for selection among computer integrated manufacturing systems, Computers in Industry 51(1): 13-29.

http://dx.doi.org/10.1016/S0166-3615(03)00029-0

Cebeci, U.; Ruan, D. 2007. A Multi-Attribute comparison of Turkish quality consultants by Fuzzy AHP, International Journal of Information Technology \& Decision Making 6(1): 191-207. http://dx.doi.org/10.1142/S0219622007002423

Chang, D. Y. 1996. Applications of extent analysis method on fuzzy AHP, European Journal of Operational Research 95: 649-655. http://dx.doi.org/10.1016/0377-2217(95)00300-2

Dolo, G.; Mackenzie, S. 2010. Impact of telecenter tools on wellbeing and community: a case study and conceptual model of the Malian experience, Fielding Graduate University No. 3426931, 266. 
Efendigil, T.; Önüt, S.; Kongar, E. 2008. A holistic approach for selecting a third-party reverse logistics provider in the presence of vagueness, Computers and Industrial Engineering 54(2): 269-287. http://dx.doi.org/10.1016/j.cie.2007.07.009

Fillip, B.; Foote, D. 2007. Making the Connection: Scaling Telecenters for Development. Washington, D.C: Academy for Education Development.

Hashemkhani Zolfani, S.; Radfar, I.; Basirat Baygi, M.; Khalafi, S. 2011. Investigating economical and social effects of rural telecenters; a report from Iran, European Journal of Economics, Finance and Administrative Sciences (41): 97-109.

Heeks, R. 2008. ICT4D 2.0: the next phase of applying ICT for international development, IEEE Computer Society 41(6): 26-33. http://dx.doi.org/10.1109/MC.2008.192

Hosman, L.; Fife, E. 2008. Improving the prospects for sustainable ICT projects in the developing world, International Journal of Media and Cultural Politics 4(1):51-69. http://dx.doi.org/10.1386/macp.4.1.51_1

Hwang, C. L.; Yoon, K. 1981. Multiple attribute decision making: a state of the art survey, in Lecture Notes in Economics and Mathematical Systems 186. Berlin: Springer-Verlag.

Jalali, A. A.; Roohani, S.; Zareh, M. A. 2005. E-Village, Iran University of Science and Technology (in Persian).

Kahraman, C.; Cebeci, U.; Ruan, D. 2004. Multi-attribute comparison of catering service companies using fuzzy AHP: the case of Turkey, International Journal of Production Economics 87: 171-184. http://dx.doi.org/10.1016/S0925-5273(03)00099-9

Kahraman, C.; Ruan, D.; Dögan, I. 2003. Fuzzy group decision making for facility location selection, Information Sciences 157: 135-153. http://dx.doi.org/10.1016/S0020-0255(03)00183-X

Kawooya, D. 2004. Universal access to ICT and lifelong learning: Uganda's experience, New Library World 105 (1206/1207): 423-428. http://dx.doi.org/10.1108/03074800410568761

Lee, S. H. 2010. Using fuzzy AHP to develop intellectual capital evaluation model for assessing their performance contribution in a university, Expert Systems with Applications 37: 4941-4947. http://dx.doi.org/10.1016/j.eswa.2009.12.020

Lin, Y.-H.; Lee, P.-C.; Chang, T.-P.; Ting, H.-I. 2008. Multi-attribute group decision making model under the condition of uncertain information, Automation in Construction 17(6): 792-797. http://dx.doi.org/10.1016/j.autcon.2008.02.011

MacCrimon, K. R. 1968. Decision making among multiple attribute alternatives: a survey and consolidated approach, Rand Memorandum RM-4823-ARPA.

Mohamed, M.; Murray, A.; Mohamed, M. 2010. The role of information and communication technology (ICT) in mobilization of sustainable development knowledge: a quantitative evaluation, Journal of Knowledge Management 14(5): 744-758. http://dx.doi.org/10.1108/13673271011074872

Naik, G. 2011. Designing a sustainable business model for e-governance embedded rural telecenters (EGERT) in India, IIMB Management Review 23: 110-121. http://dx.doi.org/10.1016/j.iimb.2011.04.001

Naik, G.; Joshi, S.; Basavaraj, K. P. 2012. Fostering inclusive growth through e-Governance Embedded Rural Telecenters (EGERT) in India, Government Information Quarterly 29: 82-89. http://dx.doi.org/10.1016/j.giq.2011.08.009

Naivinit, S. 2009. Gender, access to community telecenter and livelihood asset changes, Journal of Information, Communication \& Ethics in Society 7(2/3): 128-135.

Önüt, S.; Efendigil, T.; Karar, S. S. 2010. A combined fuzzy MCDM approach for selecting shopping center site: an example from Istanbul, Turkey, Expert Systems with Applications 37: 1973-1980. http://dx.doi.org/10.1016/j.eswa.2009.06.080

Önüt, S.; Kara, S. S.; Efendigil, T. 2008. A hybrid fuzzy MCDM approach to machine tool selection, Journal of Intelligent Manufacturing 19: 443-453. http://dx.doi.org/10.1007/s10845-008-0095-3

Rao, S. 2008. Social Development in Indian Rural Communities: Adoption of Telecentres. Central Leather Research Institute, Adyar, Chennai 600020, India. 
Saaty, T. L. 1980. The Analytic Hierarchy Process: Planning, Priority Setting, Resources Allocation. London: McGraw-Hill.

Toyama, K.; Kiri, K.; Maithreyi, L.; Nileshwar, A.; Vedashree, R.; MacGregor, R. 2004. Rural kiosks in India, Microsoft Research Technical Report, MSR-TR-2004-146 URL: http://research.microsoft.com/ pubs/70150/tr-2004-146.doc

Turskis, Z.; Zavadskas, E. K. 2010. A novel method for multiple criteria analysis: grey additive ratio assessment (ARAS-G) Method, Informatica 21(4): 597-610.

Zadeh, L. A. 1965. Fuzzy sets, Information and Control 8: 338-353. http://dx.doi.org/10.1016/S0019-9958(65)90241-X

Zavadskas, E. K.; Turskis, Z. 2010. A new additive ratio assessment (ARAS) method in multicriteria decision-making, Technological and Economic Development of Economy 16(2): 159-172. http://dx.doi.org/10.3846/tede.2010.10

Zavadskas, E. K.; Turskis, Z. 2011. Multiple criteria decision making (MCDM) methods in economics: an overview, Technological and Economic Development of Economy 17(2): 397-427. http://dx.doi.org/10.3846/20294913.2011.593291

Zavadskas, E. K.; Turskis, Z.; Tamosaitiene, J. 2010b. Risk assessment of construction projects, Journal of Civil Engineering and Management 16(1): 33-46. http://dx.doi.org/10.3846/jcem.2010.03

Zavadskas, E. K.; Vilutiene, T.; Turskis, Z.; Tamosaitiene, J. 2010a. Contractor selection for construction works by applying SAW-G and TOPSIS GREY techniques, Journal of Business Economics and Management 11(1): 34-55. http://dx.doi.org/10.3846/jbem.2010.03

\section{Appendix}

\section{Gharnabad Village}

Gharnabad village is located in 20th $\mathrm{Km}$. of Gorgan in Golestan. Most of the people of Gharnabad are farmers and ranchers; some of them also have freelance jobs and industrial jobs. Agricultural products of this village are: cotton, wheat, barley, rice, potato, and soya bean. In the area of ranching, they generally breed cows and they are at primary stage of self-efficiency in production.

The first rural telecenter of Iran was established in Gharnabad in 2004 based on the scope of economic, cultural and social development applying IT findings and communication and through villagers' assistance.

In this center, all state organizations as connectors of electronic government can deliver most of their services in an integrated way to villagers in the village. Moreover, this center is a place for accessing the villagers to virtual education, virtual library, electronic business, electronic banking and other computer and internet related issues. The approach of establishing rural telecenter is mostly economical. These telecenters are assumed to be influential in social and cultural affairs through financing and bring an operational form out of future information community.

This telecenter was built in a two floor building each one has 280 square meters area. 
The first floor has an amphitheater, internet services provider (ISP), Quran education classes, English language and agriculture promotion for different ages of girls, boys, men, women and children.

The second floor is designed for IT research center and rural communication. In this center all state organizations have suitable virtual space in order to perform their required researches together or obtain information and statistics required by related organizations in village, and deliver their services to the villagers directly in situ. This center gives the student the opportunity to perform their researches in shorter time and higher quality through ADSL of center and make the villagers engaged in research.

This center, besides its internal network, provides services needed by villagers through ISP so that they can use functional services of center and remote users can have job and find job all over the world.

Electronic books that are stored and read out in multimedia form in data sector can connect illiterate and uneducated to the world of knowledge by sound and film and be effective in productivity. The most important factor of growth of a rural community is optimizing its cultural, social and economic condition that through establishing this telecenter we witnessed the growth of those factors in Gharnabad village. It is worth mentioning that a branch of post bank is located in this center.

\section{Livan Village}

Eastern Livan village is located in Golestan province and southwest of Bandar Gaz and it is $10 \mathrm{Km}$. far from Bandar Gaz. From the north, this village ends to Caspian Sea, from the south, it ends to the forests of Albors mountains (Jahan Moora), from the east, and it ends to Nokandeh city and from the west it reachs to Hashtikeh village. The second rural telecenter of Iran inaugurated in autumn of 2005 in eastern Livan village. This center was run with the effort of villagers and private and governmental sectors' support. This telecenter is alike the first one regarding its extent and facilities. In this center, like Gharnabad's rural telecenter, several services are presented such as: electronic banking, promotional and computer education, research works, remote working services, and post and internet services. Holding different meetings of local non-governmental associations and organizations and diverse training for different governmental sections are done here, hence this center is considered effective by the youth and authorities.

Regarding high number of educated people in this village and surrounding villages, it is predicted that this center would become a place for holding educational courses up to university levels and used as a connecting point of the region with virtual universities for developing remote education.

\section{Bala Jade Village}

Bala Jade is a beautiful village in Alborz northern slope having dense forest in its south which has impressive landscape. This village is located in Golestan province and in the central part of Kordkoy. Bala Jade has mild climate due to its vicinity of the forest, the sea and the mountain. It is cold in winter and mild in summer. There are two rivers on the east and west 
of the village. It has also scenic heels named Anar heel, Noordele and Sezdar natural heel. The castles of Bala Jade are Tagh Castle, Shah neshin castle and Ghasran Castle.

This telecenter is alike the first and second one regarding its extent and facilities. In this center, several services are presented such as: electronic banking, doing researches, distant education especially for illiterate or low-literate people, technical and professional training, training health related issues, training dealing with natural events and post and internet services.

Sarfaraz HASHEMKHANI ZOLFANI got a B.S in Industrial Management and M.S. in Industrial Engineering- Productivity and System Management from Shomal University of Amol, Iran. He was accepted in M.S. without national exam because he was ranked as the top student and regarding his good GPA in B.S. He is the author of more than 40 scientific papers in International Conferences and International Journals which were published, accepted or under reviewing. His research interests include Performance Evaluation, Strategic Management, Decision-making Theory, Supply Chain Management, (Fuzzy) Multi Criteria Decision Making and Marketing.

Maedeh SEDAGHAT got a B.S. in English Language Translation and an M.S. in Executive Master of Business Administration (EMBA). She is a graduate of Payame Noor University, Babol, Iran. She was graduated with high GPA in both B.S and M.S courses. She is the author of more than 10 scientific papers in International Journals which were published, accepted or under reviewing. Her research interests include Productivity Improvement, Entrepreneurship, Outsourcing, Performance Evaluation, Decision-making Theory, Supply Chain Management and (Fuzzy) Multi Criteria Decision Making.

Edmundas Kazimieras ZAVADSKAS. Prof., Head of the Department of Construction Technology and Management at Vilnius Gediminas Technical University, Vilnius, Lithuania. He has a PhD in Building Structures (1973) and Dr Sc. (1987) in Building Technology and Management. He is a member of the Lithuanian and several foreign Academies of Sciences. He is Doctore Honoris Causa at Poznan, SaintPetersburg, and Kiev universities as well as a member of international organisations; he has been a member of steering and programme committees at many international conferences. E. K. Zavadskas is a member of editorial boards of several research journals. He is the author and co-author of more than 400 papers and a number of monographs in Lithuanian, English, German and Russian. Research interests are: building technology and management, decision-making theory, automation in design and decision support systems. 